\title{
Bali Hari Ini: \\ Permasalahan Kepariwisataan dan Solusinya
}

\author{
AA Gede Yuniartha Putra \\ Dinas Pariwisata Provinsi Bali
}

\begin{abstract}
Bali tourism that already has such a large name in the global context. As a result of the development of tourist visits, various tourism facilities were established such as restaurants, artshop, art market, entertainment centers, and recreation places in the tourist destination and around tourist attractions. Tourism in Bali is very meaningfull to the tourism industry and local communities. However, this international tourist destination has problems here and there. This study finds that the problems faced are tourism destinations, tourism institutions, tourism marketing, and tourism industry. The problems have been handled significantly. Nevertheless, in the future, it is hoped that tourism will be increasingly enhanced in all its respects so that this business will also increasingly provide welfare for all involved.
\end{abstract}

Keywords: tourism, tourists, problems, solutions.

\section{PENDAHULUAN}

Budaya Bali terkenal dengan keunikannya dan sudah dikenal sampai tingkat internasional, sehingga ada pendapat yang mengatakan bahwa Bali merupakan daerah pariwisata yang menonjolkan kebudayaannya. Melalui berbagai media Bali dipromosikan ke seluruh manca negara baik melalui media elektronik maupun dari cerita-cerita yang dibawa oleh wisatwan yang pernah datang ke Bali. Kekaguman para wisatawan asing akan Bali menggugah mereka untuk memberi gelar, istilah ataupun nama lain terhadap Bali seperti tagline pariwisata kita di Bali saat ini, yaitu BALI The Island of God.

Sebagai akibat dari perkembangan kunjungan wisatawan, berbagai sarana penunjang pariwisata mulai didirikan seperti restoran, artshop, pasar seni, pusat hiburan, dan tempat rekreasi mulai tumbuh dengan pesat di pusat hunian wisata ataupun di kawasan objek wisata. Akibatnya, para wisatawan memiliki berbagai pilihan dalam menikmati liburan mereka di Bali. Masa-masa 
berikutnya, sarana hunian wisata lalu tumbuh dengan sangat pesat di pusat hunian wisata terutama di daerah Badung, Denpasar, Gianyar, Kawasan Pantai Kuta, Jimbaran, Ungasan menjadi kawasan hunian wisata di Kabupaten Badung, Sanur, dan pusat kota untuk kawasan Denpasar. Ubud, Kedewatan, Payangan, dan Tegalalang menjadi pengembangan hunian wisata di daerah Gianyar.

Mengendalikan perkembangan yang amat pesat tersebut, pemerintah Daerah Bali kemudian menetapkan 15 kawasan di Bali sebagai daerah hunian wisata berikut sarana penunjangnya seperti restoran dan pusat perbelanjaan. Hingga kini, Bali memiliki lebih dari 130.000 kamar hotel terdiri dari kelas Pondok Wisata, Melati, hingga Bintang 5. Sarana hotel-hotel tersebut tampil dalam berbagai variasi bentuk mulai dari model rumah, standar hotel, villa, bungalow, dengan variasi harga jual. Keberagaman ini memberi nilai lebih bagi Bali karena menawarkan banyak pilihan kepada para wisatawan.

Berikut ini disajikan Jumlah Kunjungan Wisatawan Mancanegara selama lima tahun terakhir adalah sebagai berikut.

\begin{tabular}{|cc|}
\hline Tahun & Jumlah Kunjungan Wisatawan Mancanegara \\
\hline 2013 & 3.278 .598 orang \\
2014 & 3.766 .638 orang \\
2015 & $4,001,835$ orang \\
2016 & $4,927,937$ orang \\
\hline 2017 & $5,381,830$ orang \\
\hline
\end{tabular}

Sementara Jumlah Kunjungan Wisatawan Nusantara selama lima tahun terakhir adalah sebagai berikut.

\begin{tabular}{|cc|}
\hline Tahun & Jumlah Kunjungan Wisatawan Nusantara \\
\hline 2013 & 7.548 .156 orang \\
2014 & 6.394 .307 orang \\
2015 & $7,147,100$ orang \\
2016 & $8,643,680$ orang \\
2017 & $6,904,377$ orang (data per/november) \\
\hline
\end{tabular}

Berikut ini disajikan Rata-rata Lama Tinggal Wisatawan Mancanegara selama lima tahun terakhir adalah sebagai berikut. 


\begin{tabular}{cc}
\hline Tahun & Rata-rata Tinggal Wisatawan Mancanegara \\
2013 & 9.60 hari \\
2014 & 9.11 hari \\
2015 & 9,87 hari \\
2016 & 10,08 hari \\
2017 & 10,45 hari \\
\hline
\end{tabular}

Berikut ini disajikan Rata-rata Lama Tinggal Wisatawan Nusantara selama lima tahun terakhir adalah sebagai berikut.

\begin{tabular}{cc}
\hline Tahun & Rata-rata Lama Tinggal Wisatawan Nusantara \\
2013 & 3.7 hari \\
2014 & 3,8 hari \\
2015 & 4,0 hari \\
2016 & 3,8 hari \\
2017 & 4,3 hari \\
\hline
\end{tabular}

Berikut ini disajikan Rata-rata Pengeluaran Wisatawan Mancanegara selama lima tahun terakhir adalah sebagai berikut.

\begin{tabular}{cc}
\hline Tahun & Rata-rata Pengeluaran Wisatawan Mancanegara \\
2013 & 143.33 US \$ \\
2014 & 159,53 US \$ \\
2015 & 143,92 US \$ \\
2016 & 143,45 US \$ \\
2017 & 118,98 US \$ (data per/november) \\
\hline
\end{tabular}

Berikut ini disajikan Rata-rata Pengeluaran Wisatawan Nusantara selama lima tahun terakhir adalah sebagai berikut.

\begin{tabular}{cc}
\hline Tahun & Rata-rata Pengeluaran Wisatawan Nusantara \\
2013 & Rp. 494.000 \\
2014 & Rp. 567.000 \\
2015 & Rp. 520.000 \\
2016 & Rp. 550.000 \\
2017 & Rp.469,000 (data per/november) \\
\hline
\end{tabular}


Berbagai kalangan memerkirakan bahwa destinasi dan daya tarik wisata kita telah mendekati titik jenuh dan bahkan ada yang menganggap Bali sudah over exploited (digarap secara berlebihan) sehingga dikhawatirkan akan mulai ditinggalkan oleh para wisatawan dan menjadi destination of yesterday. Tentu kita semua tidak ingin hal itu sampai terjadi. Oleh karena itu kini saatnya kita harus berbuat sekecil apapun kontribusi kita, harus mulai berbenah dan membenahi apa-apa yang kurang baik, memerbaiki sistem dan pola pengelolaan destinasi yang terbaik. Kami berkeyakinan bahwa Bali tidak akan pernah menjadi destination of yesterday apabila kita semua, baik itu stakeholder/pemangku kepentingan pariwisata Bali memiliki komitmen untuk tetap menjaga dan melestarikan budaya dan adat istiadat, di samping harus berbenah dan memerbaiki pengelolaan/manajemen destinasi dan daya tarik wisata yang ada.

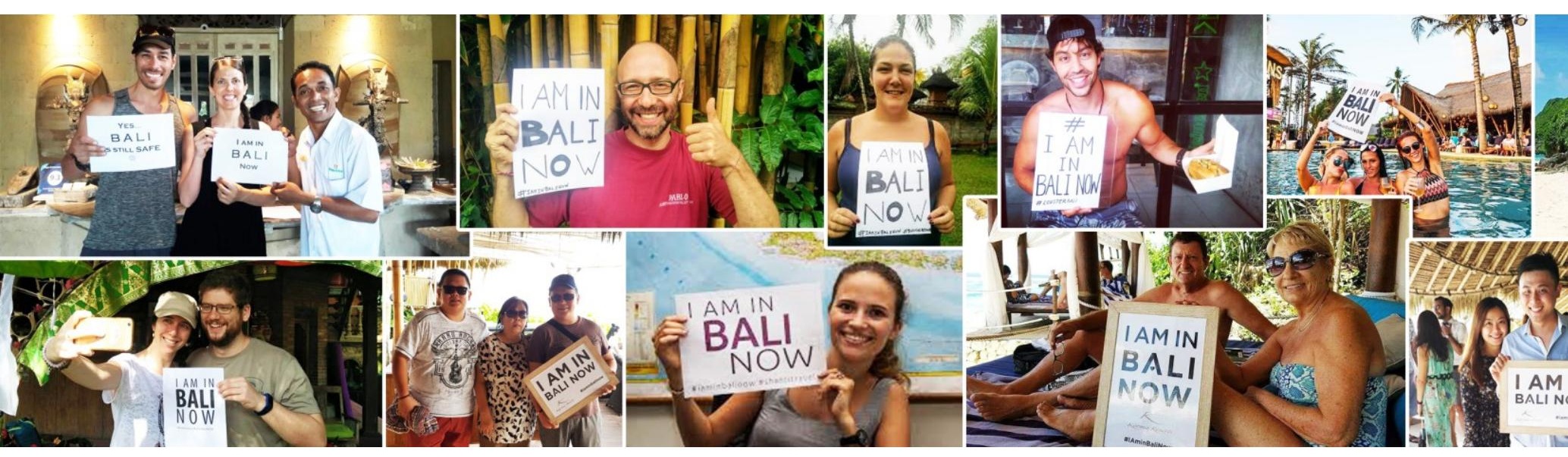

\section{PEMBAHASAN}

Permasalahan Pengembangan Kepariwisataan Bali

Adapun beberapa permasalahan krusial di bidang Pariwisata ataupun yang mempengaruhi kepariwisataan dan harus segera mendapatkan perhatian dari semua pihak adalah seperti di bawah ini.

\section{Permasalahan Destinasi Pariwisata}

Adanya ketimpangan pembangunan pariwisata antara Bali selatan dan Bali utara. Adanya ketimpangan pembangunan pariwisata atau tidak meratanya 
pembangunan antara Bali selatan dan Bali utara tersebut tidak saja di dalam hal pembangunan fisik dan infrastruktur akan tetapi juga dalam hal pembangunan SDM Pariwisata lokal. Hal ini tentu saja harus mendapat perhatian Khusus dari pemerintah Daerah Provinsi dan Kab/Kota. Meningkatnya kualitas destinasi haruslah dilakukan sebagai usaha menyeluruh bagi semua elemen produk wisata, dari transportasi, hotel, restoran, objek wisata, dan tentu juga pelayanan yang baik kepada wisatawan. Kalau wisatawan merasa takut melakukan perjalanan ke Bali dengan alasan keselamatan penumpang tidak terjamin, artinya kita harus meningkatkan kualitas transportasi yang ada. Kalau hotel sepi wisatawan ini merupakan efek domino dari persoalan yang lain karena wisatawan datang ke Bali tidak hanya untuk tinggal di hotel saja. Bagaimana wisatawan mau datang ke Bali jika objek wisata dan komponen lainnya tidak sesuai dengan harapan wisatawan. Taman kota yang tidak terawat dan langkanya ruang hijau terbuka juga memerburuk kesan kota ditambah kemacetan terutama di daerah pariwisata dan maraknya aksi premanisme yang juga harus mendapatkan perhatian serius dari pihak yang terkait.

\section{Permasalahan Kelembagaan Pariwisata}

Masih kurangnya

kualitas dan kemampuan SDM lokal Bali baik di bidang skill dan kemampuan serta wawasan

kepariwisataan.

Pada kenyataannya sumber daya manusia pariwisata Bali khususnya orangorang Bali belum memiliki kualifikasi yang

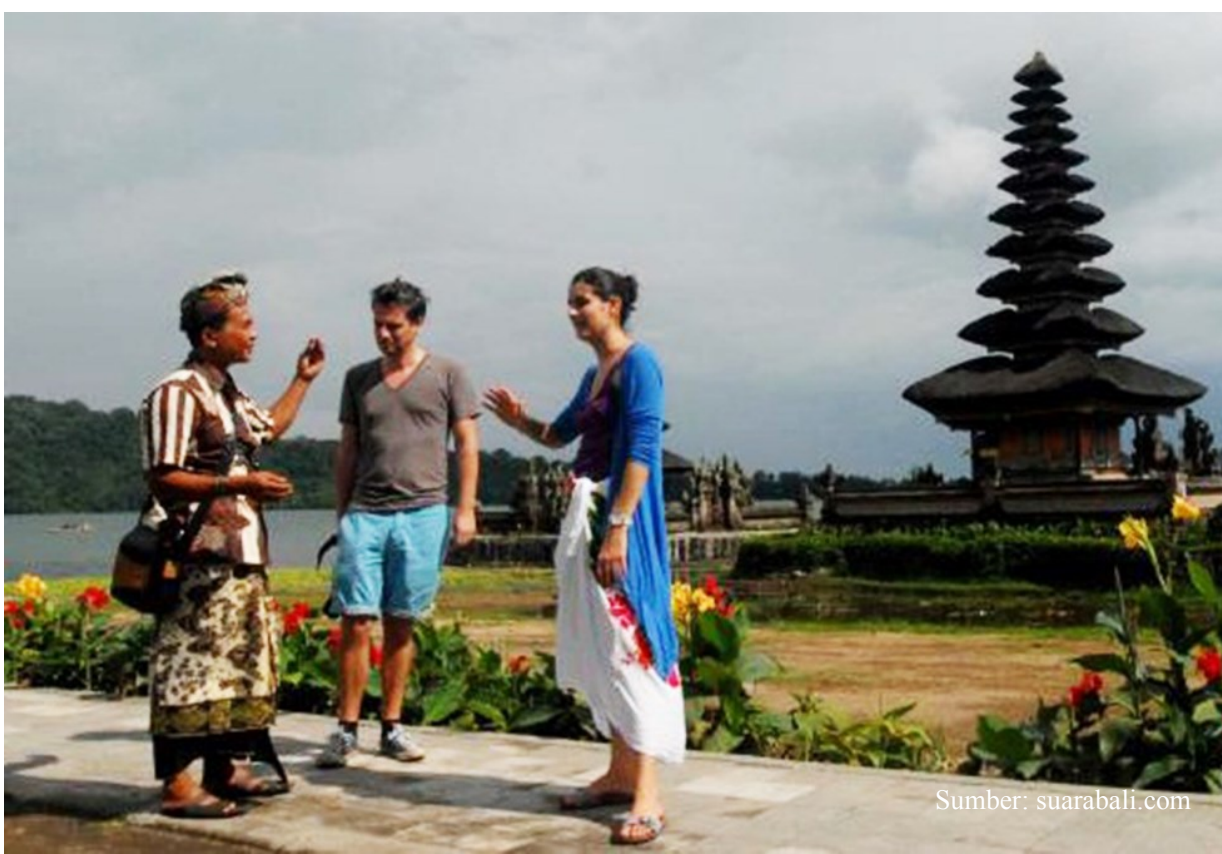


sesuai dengan permintaan wisatawan. Ini dapat dilihat dengan jelas di kebanyakan industri pariwisata yang mana orang-orang Bali hanya menduduki posisi-posisi sebagai front liner yang memiliki pekerjaan yang cukup berat namun mendapatkan penghasilan yang jauh lebih sedikit daripada posisi-posisi di tingkat manajer (managerial position) yang umumnya dipegang oleh orangorang dari luar Bali dan bahkan luar negeri. Pelayanan merupakan hal yang mutlak diperlukan dalam industri pariwisata dan merupakan salah satu tuntutan wisatawan pada saat melakukan kegiatan menghabiskan waktu luang untuk perjalanan wisata. Untuk memberikan jaminan pelayanan yang memuasakan kepada wisatawan diperlukan penyediaan sumber daya manusia (human resource) yang berkompetensi, berkualitas, professional, dan berstandar internasional. SDM pariwisata lokal yang bergerak di bidang pariwisata, kemampuan dan wawasannya perlu ditingkatkan dan perlu dibenahi agar SDM pariwisata Lokal Bali bisa bersaing dengan SDM Luar terutama di dalam era perdagangan bebas MEA.

\section{Permasalahan Pemasaran Pariwisata}

Walaupun Bali sudah terkenal di seluruh dunia sebagai salah satu Destinasi Pariwisata Favorit, akan tetapi promosi tentang Bali harus tetap dilakukan karena adanya beberapa destinasi baru di luar Bali yang gencar berpromosi dalam menarik wisatawan. Namun dengan terbatasnya dana berpromosi membuat kita tidak bisa mengikuti semua event-event penting pariwisata baik skala nasional maupun internasional.

\section{Permasalahan Industri Pariwisata}

Industri pariwisata Bali seperti Usaha Biro Perjalanan Wisata, Hotel dan Restaurant serta industri usaha lain yang bergerak di bidang pariwisata perlu mendapatkan perhatian khusus terutama di dalam hal sejauh mana industri pariwisata tersebut mampu berdaya saing sehingga dapat menggerakkan dan meningkatkan perekonomian daerah. 
Solusi Permasalahan Kepariwisataan Bali

Melihat permasalahan-permasalahan tersebut pemerintah terus berupaya melakukan pembenahan dalam berbagai kegiatan dan langkah-langkah nyata untuk mengatasi dan meminimalisir permasalahan-permasalahan tersebut.

\section{Solusi Destinasi Pariwisata}

Untuk mewujudkan destinasi pariwisata yang aman, nyaman, menarik dengan mengedepankan kekayaan dan keragaman potensi daya tarik wisata berwawasan lingkungan berdasarkan budaya Bali bisa dilakukan dengan pemerataan pembangunan pariwisata baik di bid sarana dan infrastruktur serta SDM pariwisata lokal di luar Bali Selatan. Salah satu strategi pengembangan Pariwisata Alternatif tersebut adalah pengembangan Desa Wisata, Agrowisata dan Ekowisata. Karena dari segi geografis dan letak wilayah, Bali Utara, Timur dan Barat memang sangat memungkinkan dan mendukung untuk dikembangkannya pariwisata alternatif tersebut mengingat potensinya masih mengandalkan keindahan alam dan budaya.

Pembangunan pariwisata harus dapat menggunakan sumber daya dengan berkelanjutan yang artinya kegiatan-kegiatan harus menghindari penggunaan sumber daya yang tidak dapat diperbaharui (irreversible) secara berlebihan. Hal ini juga didukung dengan keterkaitan lokal dalam tahap perencanaan, pembangunan, dan pelaksanaan sehingga pembagian keuntungan yang adil dapat diwujudkan. Dalam pelaksanaannya, kegiatan pariwisata harus menjamin bahwa sumber daya alam dan buatan dapat dipelihara dan diperbaiki dengan menggunakan kriteria-kriteria dan standarstandar internasional.

Adapun kegiatan yang bisa dilakukan untuk mengatasi ketimpangan pembangunan antara Bali Selatan dan Utara adalah,

1. Pengembangan Desa Wisata (Desa Budaya, Agrowisata, Ekowisata).

2. Pengembangan Wisata Spiritual (Spiritual Tourism).

3. Pengembangan Wisata Tirta/Bahari (Marine Tourism).

4. Pengembangan Wisata Cruise (Tanah Ampo, Benoa, Celukan Bawang).

5. Pengembangan Wisata Olah Raga (Sport Tourism). 
6. Pengembangan Wisata Pertanian (Agricultural Tourism).

7. Pengembangan Wisata Kuliner (Culinary Tourism).

8. Pengembangan Wisata MICE (Meeting, Incentif, Conference/Convention and Exhibition).

\section{Solusi Kelembagaan Pariwisata}

Untuk mengatasi permasalahan di bidang pengembangan SDM pariwisata lokal Bali, dan untuk mewujudkan organisasi pemerintah provinsi, swasta dan masyarakat, regulasi dan mekanisme yang efektif dan efisien, bisa dilakukan dengan memerbanyak pelatihan-pelatihan, penyuluhan kepariwisataan, dan melaksanakan Sertifikasi Kompetensi di bidang Pariwisata. Untuk itulah seharusnya pekerja di sektor pariwisata agar ikut serta dalam sertifikasi profesi pariwisata agar bisa bersaing dalam era globalisasi

Di samping itu, Pembangunan pariwisata di Bali harus bisa menawarkan lapangan pekerjaan yang berkualitas untuk masyarakat setempat. Fasilitas penunjang kepariwisataan seperti hotel, restoran, dan sebagainya seharusnya dapat dikembangkan dan dipelihara oleh masyarakat setempat. Beberapa pengalaman menunjukkan bahwa pendidikan dan pelatihan bagi penduduk setempat serta kemudahan akses untuk para pelaku bisnis/wirausahawan setempat benar-benar dibutuhkan dalam mewujudkan kepemilikan lokal. Lebih lanjut, keterlibatan (linkages) antara pelaku-pelaku bisnis dengan masyarakat lokal harus diupayakan dalam menunjang kepemilikan lokal tersebut.

Adapun kegiatan yang bisa dilakukan untuk mengatasi permasalahan randahnya kualitas SDM Pariwisata adalah:

1. Pelatihan/Bintek Kepariwisataan.

2. Sertifikasi Kompetensi dan Sertifikasi Usaha di Bidang Pariwisata.

3. Penyuluhan Sadar Wisata kepada POKDARWIS, Pelajar, dan Masyarakat.

4. Pemilihan Jegeg Bagus Bali sebagai Duta Wisata Provinsi Bali. 


\section{Solusi Pemasaran Pariwisata}

Promosi pariwisata Bali saat ini masih terkesan sendiri-sendiri dan kurang terintegrasi. Pariwisata Bali harus dikelola dengan konsep One Island Manajement agar terjadi pemerataan pembangunan pariwisata di berbagai daerah. Di samping itu, Industri pariwisata Bali dilanda kelesuan akut sebagai dampak erupsi Gunung Agung. Untuk mengembalikan situasi kembali normal, promosi menjadi langkah paling realistis. Di Bali, spirit kemanusiaan tercermin dalam konsep Tri Hita Karana yakni menjaga keseimbangan hubungan antara manusia, lingkungan dan Tuhan. Jadi nilai spiritual dapat dinikmati wisatawan, tidak hanya melalui ritual tetapi dengan interaksi dengan warga lokal dan menempatkan turis sebagai manusia seutuhnya. Sesuai Tugas Pokok dan Fungsi Dinas Pariwisata, dan untuk mewujudkan pemasaran pariwisata yang terpadu, efektif, efesien, terukur, dan berkualitas perlu dilakukan promosi pariwisata yang berkelanjutan dengan dukungan dana yang memadai serta membuat perencanaan SOP yang jelas.

Adapun kegiatan yang bisa dilakukan untuk mengatasi permasalahan di bidang pemasaran dan promosi pariwisata adalah, pertama, melalui promosi secara langsung maupun tidak langsung. Promosi langsung antara lain dengan mengikuti event-event di dalam maupun luar negeri, road show, sales mission, Promosi tidak langsung antara lain melalui media cetak, elektronik dan penyebaran brosur. Kedua, pelaksanaan ITOP Forum. Ketiga, pelaksanaan Forum Kerjasama Mitra Praja

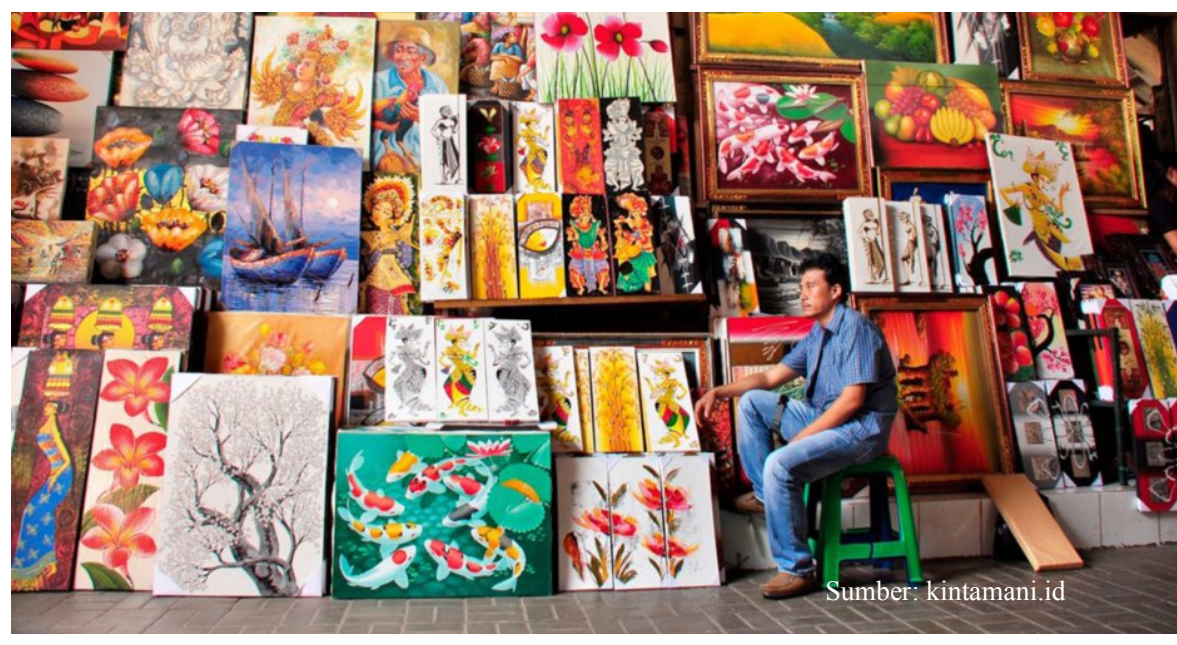
Utama (MPU). 
4. Solusi Industri Pariwisata

Untuk meningkatkan daya saing industri pariwisata yang kredibel, bertanggung jawab terhadap lingkungan dan sosial budaya perlu dilaksanakannya Sertifikasi Usaha di bidang pariwisata. Bagi para pelaku bisnis pariwisata, sertifikasi usaha pariwisata sangat dibutuhkan guna pengembangan kegiatan kepariwisataan nasional dalam menghadapi persaingan globalisasi dan liberalisasi sektor jasa baik di tingkat regional dan internasional. Sertifikasi Usaha Pariwisata merupakan amanat Undang-undang Nomor 10 Tahun 2009 tentang Kepariwisataan, di mana pada Pasal 16 dijelaskan bahwa Sertifikasi adalah proses pemberian sertifikat kepada usaha dan pekerja pariwisata untuk mendukung peningkatan mutu produk pariwisata, pelayanan, dan pengelolaan kepariwisataan.

Adapun kegiatan yang bisa dilakukan untuk mengatasi permasalahan di bidang Industri Pariwisata adalah:

1. Pembinaan Usaha Sarana Pariwisata.

2. Pembinaan Usaha Jasa Pariwisata.

3. Pembinaan Usaha Ekonomi Kreatif.

\section{PENUTUP}

Pulau Dewata selama ini dikenal sebagai surganya dunia. Bahkan, tak hanya orang Indonesia saja yang mengakui pulau itu sebagai pulau wisata paling indah. Wisatawan dunia bahkan menobatkan Pulau Bali sebagai pulau wisata terbaik dunia. Hebatnya, predikat ini tak hanya sekali disandang pulau kecil di timur Pulau Jawa itu. Tentu ini merupakan kebanggaan kita bersama. Apalagi, mengingat beberapa kali Bali diguncang peristiwa bom yang mengguncang dunia pariwisata kita dan yang terakhir adalah adanya erupsi Gunung Agung sehingga pariwisata Bali menjadi lesu dan mempengaruhi seluruh aspek kepariwisataan Bali.

Untuk saat ini, dan dengan sebuah harapan, yakni agar Bali khususnya, tetap aman dan nyaman dikunjungi. Baik oleh wisatawan lokal maupun asing. Mengingat terjadinya erupsi Gunung Agung yang sedikit tidaknya membawa dampak kurang baik terhadap Pariwisata Bali dengan menurunnya jumlah 
kunjungan wisman ke Bali. Bagi kita, hal ini tentu juga harus bisa dijadikan sebagai sarana introspeksi untuk terus meningkatkan kualitas pariwisata Bali. Namun, keindahan Alam Bali, Kekuatan adat istiadat dan budayanya, serta keramahtamahan warga Bali secara keseluruhan diharap bisa mendatangkan sebanyak mungkin wisatawan, utamanya di tahun yang akan datang dan bagi kemajuan perkembangan kepariwisataan Bali ke depannya.

Untuk mengatasi permasalahan di bidang destinasi pariwisata Bali, dan memersempit kesenjangan di Bali Selatan dan Utara tersebut tampaknya perlu segera dibuatkan peraturan daerah (Perda) yang mengharuskan pelaku usaha jasa pariwisata turut mengembangkan dan memberdayakan masyarakat agar menjadi kekuatan untuk menekan investor agar kegiatannya tidak semata-mata hanya mengeruk keuntungan akan tetapi ikut membantu mengembangkan destinasi dan memberdayakan masyarakatnya.

Untuk mengatasi permasalahan di bidang pengembangan SDM pariwisata lokal Bali bisa dilakukan dengan memerbanyak pelatihan-pelatihan, penyuluhan kepariwisataan, dan melaksanakan Sertifikasi Kompetensi di bidang Pariwisata terutama sertifikasi kompetensi bagi SDM Pariwisata Bali sehingga kemampuan, wawasan dan skill kepariwisataan yang dimiliki mempunyai daya saing dan diakui.

Promosi pariwisata Bali saat ini masih terkesan sendiri-sendiri dan kurang terintegrasi. Pariwisata Bali harus dikelola dengan konsep One Island Management agar terjadi pemerataan pembangunan pariwisata di berbagai daerah. Promosi dengan mengedepankan spirit kemanusiaan (human spirit) dicirikan dengan perilaku jujur dan mengajak wisatawan untuk turut aktif dalam berbagai atraksi wisata.

Untuk meningkatkan daya saing industri pariwisata yang kredibel, bertanggung jawab terhadap lingkungan dan sosial budaya perlu dilaksanakannya Sertifikasi Usaha di bidang pariwisata. Sertifikasi Usaha Pariwisata merupakan amanat Undang-undang Nomor 10 Tahun 2009 tentang Kepariwisataan, di mana pada Pasal 16 dijelaskan bahwa Sertifikasi adalah proses pemberian sertifikat kepada usaha dan pekerja pariwisata untuk 
mendukung peningkatan mutu produk pariwisata, pelayanan, dan pengelolaan kepariwisataan.

\section{REFERENSI}

Dinas Pariwisata Provinsi Bali. 2017. Statistik Pariwisata Bali. Denpasar: Dinas Pariwisata Provinsi Bali.

Peraturan Daerah Nomor 2 Tahun 2012 tentang Kepariwisataan Budaya Bali.

Undang-undang Republik Indonesia Nomor 10 Tahun 2009 tentang Kepariwisataan. 